\title{
Concentrations of Trace Elements in Bottled Water Consumed in Angono, Philippines
}

\author{
Seiji Maruyama, ${ }^{1}$ Hisaaki Kato, ${ }^{2}$ Takafumi Hirata ${ }^{3,4}$ and Noel R. Juban ${ }^{5}$ \\ ${ }^{1}$ Kyoto Fission-Track Co., Ltd., Kyoto, Japan \\ ${ }^{2}$ The Institute of Scientific and Industrial Research, Osaka University, Osaka, Japan \\ ${ }^{3}$ Department of Geology and Mineralogy, Faculty of Science, Kyoto University, Kyoto, Japan \\ ${ }^{4}$ Geochemical Research Center, Graduate School of Science, The University of Tokyo, Tokyo, Japan \\ ${ }^{5}$ Department of Clinical Epidemiology, College of Medicine, University of the Philippines Manila
}

\begin{abstract}
Introduction. We analyzed the concentrations of the trace elements [chromium (Cr), arsenic (As), cadmium (Cd), cesium $(\mathrm{Cs})$, lead $(\mathrm{Pb})$, thorium $(\mathrm{Th})$, and uranium $(\mathrm{U})]$ in commercial bottled water consumed in the town of Angono, Rizal province, Luzon island, Philippines to evaluate the health risks of the trace elements in drinking water. There are some arguments that water resources available in the Philippines are heavily polluted by various materials, in particular heavy metal elements.
\end{abstract}

Method. The concentrations of seven trace elements in commercial bottled water produced and consumed in the Philippines were analyzed using a solution nebulization inductively coupled plasma mass spectrometry (SN-ICP-MS).

Result. The concentrations of the trace elements except for Cs, which does not yet have a WHO guideline value, in the locally produced bottled water were below the WHO guideline values. The Cs concentrations $(<0.6 \mu \mathrm{g} / \mathrm{L})$ of the bottled water of the Philippines were generally similar to those of the bottled water produced and consumed in other countries such as Japan, China, and Indonesia.

Conclusion. The concentrations of trace elements in bottled water consumed in Angono, Philippines can be regarded as being at safe levels, as well as those of daily life water (i.e. tap, well, and spring water) consumed in the said town.

Key Words: Philippines, Angono, bottled water, trace element, health risk

\section{INTRODUCTION}

An evaluation of the health risks from drinking water is important for all countries. We have analyzed the concentrations of the trace elements [chromium $(\mathrm{Cr})$, arsenic $(\mathrm{As})$, cadmium $(\mathrm{Cd})$, cesium $(\mathrm{Cs})$, lead $(\mathrm{Pb})$, thorium $(\mathrm{Th})$, and uranium $(\mathrm{U})]$ in daily life water (i.e., tap, well, and spring water) consumed in the town of Angono, Rizal province, Luzon island, Philippines, in addition to the water samples of Angono River and Laguna Lake, by using a solution nebulization inductively coupled plasma mass spectrometry (SN-ICP-MS) to evaluate the health risks of the trace elements in daily life water. ${ }^{1}$ Some elements such as $\mathrm{Cr}$, As, $\mathrm{Cd}, \mathrm{Pb}$. and $\mathrm{U}$ can cause biochemical toxicities to the human body, and radioactive elements such as $\mathrm{Th}$ and $\mathrm{U}$ can also present radiological hazards. The WHO guideline values are

Corresponding author: Seiji Maruyama Kyoto Fission-Track Co., Ltd., 44-4 Oomiyaminamitajiri-cho, Kita-ku, Kyoto 603-8832, Japan

Email: ojigibito@icloud.com as follows: $\mathrm{Cr}: 50 \mu \mathrm{g} / \mathrm{L}$, As: $10 \mu \mathrm{g} / \mathrm{L}, \mathrm{Cd}: 3 \mu \mathrm{g} / \mathrm{L}, \mathrm{Pb}: 10$ $\mu \mathrm{g} / \mathrm{L}$, and $\mathrm{U}: 30 \mu \mathrm{g} / \mathrm{L} .{ }^{2}$ The WHO guideline value for ${ }^{232} \mathrm{Th}$ in drinking water is $1 \mathrm{~Bq} / \mathrm{L}$, which is equivalent to $250 \mu \mathrm{g} / \mathrm{L} .{ }^{2}$ There is no WHO guideline value for the concentration of 
Cs. The standard values for $\mathrm{As}, \mathrm{Cd}$, and $\mathrm{Pb}$ of the Philippine National Standards for Drinking-Water (PNSDW) updated in $2016^{3}$ are the same as the WHO guideline values. ${ }^{2}$

There are some arguments that water resources available in the Philippines are heavily polluted by various materials, in particular heavy elements mentioned above. For example, Saito and Nakano ${ }^{4}$ and $\mathrm{Kada}^{5}$ argued that various types of water available around/in Laguna Lake are contaminated by toxic metals such as $\mathrm{Pb}$. Moreover, Solidum ${ }^{6}$ analyzed 13 drinking water samples taken from different restaurants in Metro Manila using atomic absorption spectrometry (AAS), to determine the concentrations of $\mathrm{Pb}$ and $\mathrm{Cd}$. Solidum ${ }^{6}$ reported that the analytical values of $\mathrm{Pb}$ and $\mathrm{Cd}$ were $0.193 \mathrm{mg} / \mathrm{L}(1 \sigma: 0.0544 \mathrm{mg} / \mathrm{L})$ and 0.0186 $\mathrm{mg} / \mathrm{L}(1 \sigma: 0.0241 \mathrm{mg} / \mathrm{L})$, respectively. These values are more than 19 and 6 times, respectively, higher than the WHO guideline values. ${ }^{2}$ These previous studies argued that natural/ drinking water in/around Metro Manila has been heavily polluted by heavy elements, in particular $\mathrm{Pb}$.

However, contrary to these arguments, our analytical results of the tap water consumed in Angono except for Cs ${ }^{1}$ were $<0.5 \%$ of the WHO guideline values ${ }^{2}$, with those of $\mathrm{Cd}$ being $~ 9 \%$ of the WHO guideline value. The concentrations of the trace elements in the purified tap water were generally lower than those of unpurified tap water samples, although there was a possibility that small amounts of $\mathrm{Pb}$ may have been added from the equipment used for water purification. The concentrations of the trace elements in water samples from the wells and springs in Angono were more variable than those of the tap water, and these were also significantly below the $\mathrm{WHO}$ guideline values. ${ }^{1}$ The concentrations of $\mathrm{Cs}$, whose guideline value has not been proposed by WHO, in all water samples were $<0.3 \mu \mathrm{g} / \mathrm{L} .{ }^{1}$ Considering that those in European bottled water vary up to a maximum value of $415 \mu \mathrm{g} / \mathrm{L}^{7}$, the $\mathrm{Cs}$ concentrations of the analyzed water samples can be regarded as sufficiently low ${ }^{1}$. The analytical data presented in Maruyama et al. ${ }^{1}$ demonstrated that the concentrations of these trace elements in daily water currently consumed in Angono are at safe levels. The toxicological properties of the above-mentioned seven trace elements are briefly summarized in Maruyama et al. ${ }^{1}$

As the next step, the health risks of the trace elements in bottled water produced and consumed in the Philippines need to be evaluated. At present, bottled water commonly consumed in the Philippines, as well as in many other countries such as Japan and China, is regarded as "safe" drinking water. However, to evaluate the health risks from bottled water, it is necessary to check the trace-element concentrations in the bottled water consumed in the Philippines and compare these with those of the bottled water produced in other countries.

In this paper, we present the concentrations of the abovementioned seven trace elements in bottled water consumed in Angono, Philippines in order to evaluate any health risks from these trace elements. We also compare them with those produced and consumed in the other countries such as Japan, China, and Indonesia.

\section{METHODS}

A total of nine samples of the bottled water produced in the Philippines were purchased from stores in Angono between October 9 and 12, 2015. These bottled water samples were kept at a few degrees Celsius in a cold box and refrigerator immediately after sampling, until preparation for instrumental analyses in Japan. The bottled water produced in Japan (8 samples), Spain (1), and France (1) were obtained in Japan during FY 2015. Those produced in South Korea (2 samples), China (9), and Indonesia (5) were obtained from the said countries during FY 2015. All bottled water samples were kept in the refrigerator just before the analyses.

The quantitative analyses of seven elements $(\mathrm{Cr}, \mathrm{As}$, $\mathrm{Cd}, \mathrm{Cs}, \mathrm{Pb}, \mathrm{Th}$, and $\mathrm{U}$ ) in the water samples except for those obtained in Indonesia were carried out using a Thermo Fisher Scientific iCAP Qc ICP-MS at Kyoto University. All bottled water samples were not filtered before the analyses. The additional details of the analytical procedures are described in Maruyama et al. ${ }^{1}$

The quantitative analyses of seven trace elements in the bottle water samples obtained in Indonesia were carried out using an Agilent 8800 tandem ICP mass spectrometer (ICP-MS/MS) at Shimadzu Techno-Research, Inc. The flow rates of the plasma (Ar) and auxiliary gases (Ar) were set to 15 and $0.9 \mathrm{~L} / \mathrm{min}$, respectively. That of the carrier gas was $1.0 \mathrm{~L} / \mathrm{min}$. The RF power was $1550 \mathrm{~W}$. The integration time and sweep number were $1 \mathrm{sec}$ and 100 times, respectively. Each sample was analyzed three times. Each sample was made acidic by nitric acid, and $20 \mu \mathrm{g} / \mathrm{L}$ of $\mathrm{Y}, \mathrm{In}, \mathrm{Tl}$ and 100 $\mu \mathrm{g} / \mathrm{L}$ of $\mathrm{Te}$ were added to them as the internal standards. Multi-element standard solutions SPEX XSTC-622 and Perkin Elmer ICP-MS Element Calibration Standard 2, were used for calibration. The determinations of the elements except for As were carried out in the single MS mode, and that of As was determined by using the MS/ MS mode. The collision gases were introduced during the analyses of $\mathrm{Cr}(\mathrm{He} ; 5.0 \mathrm{~mL} / \mathrm{min})$ and $\mathrm{As}_{2}\left(\mathrm{H}_{2} ; 7.0 \mathrm{~mL} / \mathrm{min}\right)$.

The $\mathrm{Pb}$ concentrations of the bottled water samples whose Th and $\mathrm{U}$ concentrations were shown in Maruyama et al. ${ }^{8}$ were determined together with the $\mathrm{Th}-\mathrm{U}$ concentrations during FY 2013. The analytical conditions of the $\mathrm{Pb}$ concentrations are described in Maruyama et al. ${ }^{8}$ The flow rate of the collision cell gas $\left(\mathrm{He}+\mathrm{H}_{2}\right)$ was the same as that for the analyses by using the $\mathrm{iCAP} \mathrm{Qc}$ instrument $(4.5-5.5 \mathrm{~mL} / \mathrm{min}){ }^{1}$

\section{RESULTS AND DISCUSSION}

\section{Bottled water samples of the Philippines}

The concentrations of the seven trace elements in the bottled water samples of the Philippines are summarized 
in Table 1. The WHO guideline values ${ }^{1}$ are also shown in Table 1. The concentrations of $\mathrm{Cr}, \mathrm{As}, \mathrm{Cd}, \mathrm{Pb}$, and $\mathrm{U}$ in all the bottled water samples analyzed in this study were substantially below the provisional guideline values proposed by $\mathrm{WHO}{ }^{2}$ The highest values of the concentrations of $\mathrm{Cr}$, $\mathrm{As}, \mathrm{Cd}, \mathrm{Pb}$, and $\mathrm{U}$ were $\sim 1 \%, \sim 22 \%, \sim 0.1 \%, \sim 0.5 \%$, and $\sim 0.3 \%$, respectively, of the WHO guideline values. ${ }^{2}$ (Table 1 ) Concentrations of Th were $<0.0005 \%$ of the guideline value for the natural radionuclide ${ }^{232} \mathrm{Th}$ proposed by $\mathrm{WHO}{ }^{2}$

Concentrations of the seven trace elements in the samples PHL-BW-7 and -9 were similar to each other (Table 1). In these two samples, the concentrations of As $(\sim 2.2 \mu \mathrm{g} / \mathrm{L})$ and Cs $(\sim 0.6 \mu \mathrm{g} / \mathrm{L})$ were $>3$ and $>70$ times higher, respectively, than those of the other bottled water samples $(<0.7 \mu \mathrm{g} / \mathrm{L}$ As and $<0.009 \mu \mathrm{g} / \mathrm{L}$ Cs; Table 1$)$. The analytical results listed in Table 1 suggest that PHL-BW-7 and -9 have been produced from a common water source. This presumption is supported by the fact that the mineral compositions described on the labels of these bottled waters match each other exactly, although the source of the water is not given. The production processes of the PHL-BW-7 and -9 waters may also be similar, given that mineral components of the water samples are maintained in the final product.

In comparison with PHL-BW-7 and -9, the samples PHL-BW-1, -2, and -8 exhibited lower concentrations of As, $\mathrm{Cd}, \mathrm{Cs}$, and $\mathrm{U}$ (Table 1). This suggests that these three bottled water samples may have been produced by purification processes that (partly) remove these elements from the source water. The relatively low concentrations of the elements in samples PHL-BW-4 and -6 indicate that they may also be highly purified (Table 1). The concentrations of As, $\mathrm{Cr}$, and $\mathrm{U}$ in samples PHL-BW-3 and -5 suggest that these bottled water samples may not have been subject to a production process that completely removes these mineral components from the source water (Table 1).

\section{Comparison with bottled water samples of the other countries}

The concentrations of seven trace elements in the bottled water samples produced/consumed in the other countries are shown in Tables 2 and 3. The concentrations of these elements in the bottled water samples of the Philippines were generally similar to or much lower than those of the other countries. The tendency of the trace-element concentrations of the bottled water samples of Indonesia (Table 3) seems to be relatively similar to that of the Philippines.

Some bottled water samples of the other countries shown in Table 2 exhibited considerably higher element concentrations in comparison with those of the Philippines. For example, the $U$ concentrations of some bottled water samples are 2-18 times higher than PHL-BW-3 (104 ng/L U; Table 1), and that of JPN-BW-3 (24 $\mu$ g/L U; Table 2) was more than 230 times higher than that of PHL-BW-3. Moreover, the Cs concentration of CHN-BW-9 was 200 $\mu \mathrm{g} / \mathrm{L}$. This analytical value was $\sim 320$ times as high as those of PHL-BW-7 and -9 (Table 1). The concentrations of Cs in European bottled water samples vary up to a maximum value of $415 \mu \mathrm{g} / \mathrm{L}$, and Cs is considered to be a characteristic component of "mineral water". ${ }^{7}$ Thus, the Cs concentration of CHN-BW-9 was normal as bottled mineral water, and those of the bottled water of the Philippines (Table 1) was at sufficiently low levels.

\section{Lead concentrations of bottled waters}

Generally, the $\mathrm{Pb}$ concentration seems to be treated as one of the most important factor of the quality of the drinking water, because a high intake of $\mathrm{Pb}$ can cause decreased IQ in children. ${ }^{9}{ }^{10}$ With reference to the analytical results of Saito and $\mathrm{Nakano}^{4}$, $\mathrm{Kada}^{5}$ argued that the $\mathrm{Pb}$ pollution of Laguna Lake is currently causing harmful effects on the brain development of children living around the lake. However, the trace-element concentrations, including $\mathrm{Pb}$, in the daily life water consumed in Angono ${ }^{1}$ were considerably lower

Table 1. Concentrations of seven trace elements in bottled waters produced in the Philippines

\begin{tabular}{|c|c|c|c|c|c|c|c|c|c|c|c|c|c|c|}
\hline \multirow[b]{2}{*}{$\begin{array}{c}\text { Sample } \\
\text { name }\end{array}$} & \multicolumn{2}{|c|}{$\mathrm{Cr}$} & \multicolumn{2}{|c|}{ As } & \multicolumn{2}{|c|}{$\mathrm{Cd}$} & \multicolumn{2}{|c|}{ Cs } & \multicolumn{2}{|c|}{$\mathrm{Pb}$} & \multicolumn{2}{|c|}{ Th } & \multicolumn{2}{|c|}{$\mathbf{U}$} \\
\hline & (ng/L) & $\begin{array}{l}\text { RSD } \\
(\%)\end{array}$ & (ng/L) & $\begin{array}{l}\text { RSD } \\
(\%)\end{array}$ & (ng/L) & $\begin{array}{c}\text { RSD } \\
(\%)\end{array}$ & (ng/L) & $\begin{array}{l}\text { RSD } \\
(\%)\end{array}$ & (ng/L) & $\begin{array}{l}\text { RSD } \\
(\%)\end{array}$ & (ng/L) & $\begin{array}{l}\text { RSD } \\
(\%)\end{array}$ & (ng/L) & $\begin{array}{l}\text { RSD } \\
(\%)\end{array}$ \\
\hline PHL-BW-1 & 117.4 & 2.6 & $<9.2$ & & $<0.4$ & & $<0.3$ & & 3.1 & 9.9 & 1.2 & 25.3 & $<0.1$ & \\
\hline PHL-BW-2 & 34.0 & 2.4 & 12.6 & 8.4 & $<0.4$ & & $<0.3$ & & 2.2 & 3.7 & 0.4 & 13.1 & $<0.1$ & \\
\hline PHL-BW-3 & 67.9 & 0.6 & 672.9 & 0.6 & $<0.4$ & & 9.0 & 2.3 & 1.4 & 1.2 & 0.3 & 14.8 & 103.9 & 0.3 \\
\hline PHL-BW-4 & 36.0 & 3.3 & $<9.2$ & & $<0.4$ & & $<0.3$ & & 46.2 & 2.5 & 0.2 & 5.0 & 0.1 & 4.3 \\
\hline PHL-BW-5 & 495.6 & 0.4 & 235.1 & 1.5 & $<0.4$ & & 0.9 & 7.8 & 15.2 & 2.0 & 0.9 & 3.6 & 0.2 & 5.2 \\
\hline PHL-BW-6 & 22.8 & 4.5 & 37.6 & 5.5 & $<0.4$ & & 0.4 & 3.9 & 1.2 & 2.3 & $<0.1$ & & 0.3 & 3.0 \\
\hline PHL-BW-7 & $<15.4$ & & 2193.4 & 0.9 & 2.1 & 1.8 & 625.4 & 1.1 & 1.6 & 3.1 & 1.3 & 24.3 & 5.3 & 0.8 \\
\hline PHL-BW-8 & 17.2 & 91.1 & 57.7 & 4.4 & $<0.4$ & & 3.2 & 1.5 & 5.3 & 1.9 & 0.3 & 14.6 & 1.6 & 2.4 \\
\hline PHL-BW-9 & $<15.4$ & & 2231.5 & 0.8 & 2.2 & 7.8 & 634.0 & 0.3 & 0.7 & 16.3 & 0.3 & 11.5 & 5.1 & 0.4 \\
\hline WHO value ${ }^{a}$ & 50000 & & 10000 & & 3000 & & (not pr & posed) & 10000 & & 250000 & & 30000 & \\
\hline
\end{tabular}

Notes: Values with inequality signs represent that the analytical values are below the lower limits of quantitation. RSD: Relative Standard Deviation. ${ }^{a}$ WHO provisional guideline values for $\mathrm{Cr}, \mathrm{As}, \mathrm{Cd}, \mathrm{Pb}$, and $\mathrm{U}$, and Th guideline value for the natural radionuclide ${ }^{232} \mathrm{Th}$ [2]. 
Table 2. Concentrations of seven trace elements in bottled waters produced/consumed in Japan, Spain, France, South Korea, and China

\begin{tabular}{|c|c|c|c|c|c|c|c|c|c|c|c|c|c|c|c|}
\hline \multirow{2}{*}{$\begin{array}{c}\text { Country } \\
\text { of water } \\
\text { origin }\end{array}$} & \multirow{2}{*}{$\begin{array}{c}\text { Sample } \\
\text { name }\end{array}$} & \multicolumn{2}{|c|}{$\mathrm{Cr}$} & \multicolumn{2}{|c|}{ As } & \multicolumn{2}{|l|}{$\mathrm{Cd}$} & \multicolumn{2}{|l|}{ Cs } & \multicolumn{2}{|c|}{$\mathrm{Pb}$} & \multicolumn{2}{|c|}{ Th } & \multicolumn{2}{|l|}{$\mathbf{U}$} \\
\hline & & (ng/L) & $\begin{array}{l}\text { RSD } \\
\text { (\%) }\end{array}$ & (ng/L) & $\begin{array}{l}\text { RSD } \\
\text { (\%) }\end{array}$ & (ng/L) & $\begin{array}{l}\text { RSD } \\
(\%)\end{array}$ & (ng/L) & $\begin{array}{l}\text { RSD } \\
\text { (\%) }\end{array}$ & (ng/L) & $\begin{array}{l}\text { RSD } \\
(\%)\end{array}$ & (ng/L) & $\begin{array}{l}\text { RSD } \\
\text { (\%) }\end{array}$ & (ng/L) & $\begin{array}{l}\text { RSD } \\
\text { (\%) }\end{array}$ \\
\hline \multirow[t]{8}{*}{ Japan } & JPN-BW-1 & 24.7 & 1.6 & 69.4 & 6.4 & 0.9 & 13.9 & 5.5 & 1.6 & 28.2 & 1.1 & 2.5 & 37.5 & 202.6 & 0.9 \\
\hline & JPN-BW-2 & 292.4 & 5.0 & 481.4 & 1.8 & 3.7 & 4.0 & 0.9 & 8.1 & 2.1 & 22.0 & 1.5 & 14.7 & 467.4 & 7.4 \\
\hline & JPN-BW-3 & 213.0 & 2.0 & 3875.6 & 1.5 & 1.2 & 20.7 & 81.6 & 0.7 & 3.3 & 2.3 & 0.6 & 13.5 & 24012.0 & 0.4 \\
\hline & JPN-BW-4 & 29.8 & 10.4 & 13.9 & 3.9 & $<0.3$ & & 2.0 & 5.8 & 4.6 & 0.6 & 0.4 & 7.4 & 17.4 & 3.0 \\
\hline & JPN-BW-5 & 21.0 & 3.2 & $<5.2$ & & 0.6 & 11.7 & 43.6 & 0.3 & 25.9 & 0.4 & 0.3 & 6.6 & 0.1 & 14.7 \\
\hline & JPN-BW-6 & 23.9 & 4.1 & 17.7 & 8.8 & $<0.3$ & & $<0.2$ & & 51.4 & 0.6 & 0.2 & 6.1 & 0.1 & 14.8 \\
\hline & JPN-BW-7 & 112.6 & 3.9 & 1624.9 & 1.5 & 6.9 & 4.9 & 91.3 & 1.6 & $<0.6$ & & 0.2 & 8.8 & 23.2 & 1.3 \\
\hline & JPN-BW-8 & 159.1 & 1.0 & 323.5 & 1.7 & 12.4 & 2.9 & 30.1 & 1.6 & 14.9 & 0.7 & 0.1 & 9.5 & 2.6 & 1.7 \\
\hline Spain & ESP-BW-1 & 66.3 & 1.5 & 166.5 & 1.8 & $<0.3$ & & 10.5 & 0.8 & 2.6 & 7.4 & 0.5 & 11.6 & 1811.2 & 1.1 \\
\hline France & FRA-BW-1 & 37.5 & 7.0 & 266.4 & 2.1 & 14.6 & 2.8 & 23.0 & 2.6 & $<2.4$ & & 0.7 & 33.1 & 1180.1 & 3.1 \\
\hline \multirow{2}{*}{$\begin{array}{l}\text { South } \\
\text { Korea }\end{array}$} & KOR-BW-1 & 241.5 & 1.5 & 404.4 & 1.3 & $<0.3$ & & 92.2 & 1.1 & $<0.6$ & & 0.9 & 14.3 & 36.8 & 0.5 \\
\hline & KOR-BW-2 & 184.9 & 0.9 & 495.8 & 1.5 & 1.0 & 6.0 & 63.2 & 0.7 & 4.9 & 3.9 & $<0.2$ & & 282.7 & 0.2 \\
\hline \multirow[t]{9}{*}{ China } & CHN-BW-1 & 12.8 & 6.8 & $<6.6$ & & $<0.2$ & & 0.2 & 17.6 & $<0.9$ & & 1.1 & 31.2 & $<0.1$ & \\
\hline & CHN-BW-2 & 647.5 & 0.6 & 121.9 & 2.4 & 3.5 & 3.9 & 10.1 & 1.4 & 1.9 & 2.8 & $<0.4$ & & 67.3 & 1.1 \\
\hline & CHN-BW-3 & 234.4 & 1.6 & $<6.6$ & & $<0.2$ & & 7.5 & 2.2 & 31.3 & 33.7 & $<0.4$ & & $<0.1$ & \\
\hline & CHN-BW-4 & 224.6 & 0.4 & 40.5 & 4.5 & 2.5 & 6.9 & 36.0 & 0.8 & $<0.9$ & & $<0.4$ & & 1012.9 & 0.9 \\
\hline & CHN-BW-5 & 115.8 & 2.8 & $<6.6$ & & $<0.2$ & & 0.2 & 13.3 & 2.4 & 1.9 & $<0.4$ & & 0.1 & 26.9 \\
\hline & CHN-BW-6 & 568.7 & 1.7 & 157.6 & 2.0 & 20.7 & 3.4 & 256.1 & 0.8 & 27.1 & 1.2 & $<0.4$ & & 377.9 & 0.7 \\
\hline & CHN-BW-7 & 147.4 & 0.3 & 18.1 & 7.2 & 0.5 & 11.2 & 2.5 & 1.1 & 7.6 & 1.2 & $<0.4$ & & 242.9 & 1.2 \\
\hline & CHN-BW-8 & 87.4 & 2.4 & $<6.6$ & & 3.5 & 5.4 & 62.5 & 1.4 & 12.8 & 1.1 & $<0.4$ & & 15.9 & 1.3 \\
\hline & CHN-BW-9 & 48.8 & 2.9 & 4824.7 & 0.4 & $<0.2$ & & 199239.9 & 0.3 & 0.6 & 5.4 & 0.3 & 9.4 & 818.7 & 0.4 \\
\hline
\end{tabular}

Notes: Values with inequality signs represent that the analytical values are below the lower limits of quantitation. ESP-BW-1 and FRA-BW-1 were purchased in Japan. RSD: Relative Standard Deviation.

Table 3. Concentrations of seven trace elements in bottled waters consumed in Indonesia

\begin{tabular}{ccrcrcrc}
$\begin{array}{c}\text { Sample } \\
\text { name }\end{array}$ & $\begin{array}{c}\mathrm{Cr} \\
\text { (ng/L) }\end{array}$ & $\begin{array}{c}\text { As } \\
\text { (ng/L) }\end{array}$ & $\begin{array}{c}\text { Cd } \\
\text { (ng/L) }\end{array}$ & $\begin{array}{c}\mathrm{Cs} \\
\text { (ng/L) }\end{array}$ & $\begin{array}{c}\mathrm{Pb} \\
\text { (ng/L) }\end{array}$ & $\begin{array}{c}\text { Th } \\
\text { (ng/L) }\end{array}$ & $\begin{array}{c}\text { U } \\
\text { (ng/L) }\end{array}$ \\
\hline IDN-BW-1 & $<100$ & 940 & $<5$ & 110 & $<5$ & $<2$ & 84 \\
IDN-BW-2 & $<100$ & 3400 & $<5$ & 14 & 15.0 & $<2$ & 180 \\
IDN-BW-3 & 180 & 580 & $<5$ & 260 & 9.7 & $<2$ & 110 \\
IDN-BW-4 & $<100$ & 200 & $<5$ & 39 & $<5$ & $<2$ & 31 \\
IDN-BW-5 & $<100$ & 420 & $<5$ & 160 & 7.0 & $<2$ & 42 \\
\hline
\end{tabular}

Note: Value with inequality signs represent that the analytical values are below the lower limits of quantitation.

than the WHO guideline values ${ }^{2}$. Moreover, as previously mentioned, the $\mathrm{Pb}$ concentrations of the bottled water of the Philippines were also substantially below the WHO guideline value. ${ }^{2}$ Nevertheless, we need to discuss further the $\mathrm{Pb}$ concentrations of the bottled water of the Philippines.

Tables 4 and 5 are the $\mathrm{Pb}$ concentrations in a total of 92 bottled water samples consumed in Japan, whose $U$ and Th concentrations have been published by Maruyama et al. ${ }^{8}$ The $\mathrm{Pb}$ concentrations of the bottled water produced in Japan are below $134 \mathrm{ng} / \mathrm{L}$ (DBW-K-31; Table 4), with median value of $4.8 \mathrm{ng} / \mathrm{L}$ (i.e., $<0.05 \%$ of the $\mathrm{WHO}$ guideline value $^{2}$ ). Those of the bottled water samples whose sources are outside Japan are 1-24 ng/L (Table 5). In the bottled water consumed in Japan shown in Table 2 (JPN-BW-1 to
-8, ESP-BW-1, and FRA-BW-1), the $\mathrm{Pb}$ concentrations completely overlap with the $\mathrm{Pb}$-concentration range shown in Tables 4 and 5 . In addition, those of the bottled water samples of South Korea, China (Table 2), and Indonesia (Table 3) are typically below $\sim 30 \mathrm{ng} / \mathrm{L}$.

The $\mathrm{Pb}$ concentrations of the bottled water samples of the Philippines (1-46 ng/L; Table 1) were very similar to those consumed/produced in the other countries. In other words, no bottled water of the Philippines exhibited extraordinary higher $\mathrm{Pb}$ concentration than those consumed/produced in the other countries. As with daily life water consumed in Angono $^{1}$, the $\mathrm{Pb}$ concentrations of the bottled water samples analyzed in this study were at harmless levels.

\section{CONCLUSIONS}

In order to evaluate the health risks posed by trace elements in the commercial bottled water consumed in Angono, Luzon island, Philippines, the concentrations of seven trace elements $(\mathrm{Cr}, \mathrm{As}, \mathrm{Cd}, \mathrm{Cs}, \mathrm{Pb}, \mathrm{Th}$, and $\mathrm{U})$ in the bottled water samples had been analyzed. The concentrations of the well-known toxic elements (i.e., $\mathrm{Cr}, \mathrm{As}, \mathrm{Cd}, \mathrm{Pb}$, and $\mathrm{U})$ and radioactive $\mathrm{Th}$ in all water samples were substantially below the guideline values proposed by WHO. ${ }^{2}$ Moreover, the concentrations of these trace elements in the bottled water samples of the Philippines were of the same or lower 
Table 4. Concentrations of lead in Japanese bottled waters purchased in Kyoto City (DBW-K) and those got in regions outside Kyoto City (DBW-P)

\begin{tabular}{|c|c|c|c|c|c|c|c|c|c|c|c|c|}
\hline \multicolumn{2}{|c|}{ Water source } & \multirow{2}{*}{\multicolumn{2}{|c|}{ Sample }} & \multicolumn{2}{|c|}{ Lead concentration } & \multirow{2}{*}{$\begin{array}{l}\text { Hardness } \\
\text { on label }^{\mathrm{a}}\end{array}$} & \multicolumn{2}{|c|}{ Water source } & \multirow{2}{*}{ Sample } & \multicolumn{2}{|c|}{ Lead concentration } & \multirow{2}{*}{$\begin{array}{c}\text { Hardness } \\
\text { on label }^{a}\end{array}$} \\
\hline Region & Prefecture & & & (ng/L) & RSD (\%) & & Region & Prefecture & & (ng/L) & RSD (\%) & \\
\hline \multirow{10}{*}{\multicolumn{2}{|c|}{ Hokkaido }} & DBW-K- & 1 & 28.5 & 1.5 & $S$ & Chubu & Shizuoka & DBW-K- 30 & 1.7 & 1.3 & $S$ \\
\hline & & & 2 & 81.0 & 2.3 & $S$ & & Shizuoka & 31 & 134.2 & 1.3 & $\mathrm{MH}$ \\
\hline & & & 3 & 2.1 & 4.7 & $\mathrm{MH}$ & & Shizuoka & 32 & 0.7 & 8.3 & $\mathrm{MH}$ \\
\hline & & DBW-P- & 1 & 2.1 & 4.7 & $\mathrm{~S}$ & & Yamanashi & DBW-P- 12 & 5.7 & 4.0 & $S$ \\
\hline & & & 2 & 24.6 & 1.1 & $S$ & & Nagano & 13 & 45.6 & 4.6 & S \\
\hline & & & 3 & 3.5 & 2.7 & MH & Kinki & Kyoto & DBW-K- 33 & 3.6 & 2.4 & $\mathrm{~S}$ \\
\hline & & & 4 & 2.9 & 1.5 & $\mathrm{MH}$ & & Kyoto & 34 & 6.0 & 1.0 & $\mathrm{MH}$ \\
\hline & & & 5 & 15.4 & 0.5 & $\mathrm{MH}$ & & Kyoto & 35 & 19.2 & 1.0 & ND \\
\hline & & & 6 & 2.0 & 3.5 & $\mathrm{MH}$ & & Kyoto & 36 & 4.8 & 2.4 & $\mathrm{MH}$ \\
\hline & & & 8 & 2.6 & 2.1 & $S$ & & Kyoto & 37 & 8.4 & 0.9 & $S$ \\
\hline \multirow[t]{3}{*}{ Tohoku } & Iwate & DBW-K- & 4 & 16.3 & 1.5 & $S$ & & Hyogo & 38 & 2.6 & 2.0 & $S$ \\
\hline & Yamagata & & 5 & 3.9 & 2.4 & $S$ & & Hyogo & 63 & 27.8 & 1.1 & $\mathrm{MH}$ \\
\hline & Fukushima & DBW-P- & 9 & 116.7 & 0.6 & $\mathrm{~S}^{\mathrm{b}}$ & & Shiga & 39 & 26.8 & 1.1 & S \\
\hline \multirow[t]{2}{*}{ Kanto } & Gunma & DBW-P- & 10 & 2.9 & 2.7 & $\mathrm{~S}$ & & Shiga & 40 & 0.9 & 6.3 & $S$ \\
\hline & Gunma & & 11 & 2.3 & 3.9 & $\mathrm{~S}$ & & Nara & 41 & 3.1 & 2.0 & $\mathrm{MH}$ \\
\hline \multirow[t]{25}{*}{ Chubu } & Niigata & DBW-K- & 6 & 7.8 & 2.1 & $\mathrm{~S}$ & & Wakayama & 42 & 2.3 & 3.4 & $S$ \\
\hline & Niigata & & 7 & 16.7 & 1.6 & $S$ & & Wakayama & 43 & 2.0 & 4.5 & $S$ \\
\hline & Niigata & & 8 & 2.6 & 2.8 & $S$ & & Mie & 44 & 1.9 & 3.2 & $S$ \\
\hline & Toyama & & 9 & 10.1 & 2.3 & $S$ & & Mie & 45 & 3.5 & 7.6 & $S$ \\
\hline & Toyama & & 10 & 3.7 & 2.9 & $S$ & & Mie & 46 & 20.9 & 0.7 & $\mathrm{VH}$ \\
\hline & Toyama & & 61 & 2.0 & 2.9 & $S$ & & Hyogo & DBW-P- 14 & 34.2 & 2.4 & ND \\
\hline & Fukui & & 11 & 3.0 & 2.0 & $S$ & & Mie & 15 & 5.1 & 1.9 & $\mathrm{~S}$ \\
\hline & Yamanashi & & 12 & 96.0 & 0.4 & $S$ & Chugoku & Tottori & DBW-K- 47 & 3.1 & 3.8 & $S$ \\
\hline & Yamanashi & & 13 & 38.8 & 1.5 & $S$ & $\&$ & Tottori & 48 & 2.9 & 2.8 & $S$ \\
\hline & Yamanashi & & 14 & 3.1 & 3.9 & $\mathrm{~S}$ & Shikoku & Tottori & 49 & 27.9 & 0.8 & $S$ \\
\hline & Yamanashi & & 15 & 2.6 & 3.4 & $S$ & & Tottori & 50 & 6.4 & 1.3 & $S$ \\
\hline & Yamanashi & & 16 & 1.6 & 3.1 & $S$ & & Shimane & 51 & 1.6 & 4.5 & $S$ \\
\hline & Yamanashi & & 17 & 6.2 & 1.6 & $\mathrm{~S}$ & & Shimane & 52 & 10.8 & 1.7 & $\mathrm{MH}$ \\
\hline & Yamanashi & & 62 & 7.0 & 1.4 & $S$ & & Shimane & 64 & 133.5 & 0.7 & $\mathrm{~S}$ \\
\hline & Yamanashi & & 18 & $<0.7^{c}$ & & $S$ & & Kochi & 53 & $<0.6^{c}$ & & $\mathrm{MH}$ \\
\hline & Yamanashi & & 19 & 11.4 & 2.0 & $\mathrm{~S}$ & & Tokushima & DBW-P- 7 & 97.3 & 0.4 & $\mathrm{~S}$ \\
\hline & Yamanashi & & 20 & 4.7 & 1.5 & $S$ & Kyusyu & Kumamoto & DBW-K- 54 & 5.1 & 2.6 & $\mathrm{MH}$ \\
\hline & Nagano & & 21 & 2.1 & 3.0 & $S$ & $\&$ & Oita & 55 & 3.1 & 3.8 & $S$ \\
\hline & Nagano & & 22 & 13.0 & 1.0 & $S$ & Okinawa & Miyazaki & 56 & 3.4 & 3.5 & S \\
\hline & Nagano & & 23 & 3.8 & 7.3 & $S$ & & Miyazaki & 57 & 39.2 & 1.2 & $\mathrm{MH}$ \\
\hline & Nagano & & 24 & 11.1 & 3.2 & $S$ & & Kagoshima & 58 & 7.2 & 1.6 & S \\
\hline & Nagano & & 25 & 6.6 & 2.3 & $\mathrm{~S}$ & & Kagoshima & 59 & 1.3 & 3.9 & $\mathrm{~S}$ \\
\hline & Gifu & & 26 & 5.5 & 3.3 & $S$ & & Kagoshima & 60 & 9.7 & 1.3 & $S$ \\
\hline & Gifu & & 27 & 4.0 & 2.2 & $S$ & & Okinawa & 65 & 2.5 & 7.8 & $\mathrm{H}$ \\
\hline & Gifu & & 28 & 1.9 & 2.8 & $S$ & & Oita & DBW-P- 16 & 11.2 & 1.5 & $S$ \\
\hline
\end{tabular}

Note: Sample names are common to those shown in Maruyama et al. [8]. RSD: Relative Standard Deviation.

${ }^{a}$ Classification of water hardness is based on WHO [11]. S: soft; MH: moderately hard; H: hard; VH: very hard; ND: not described on label.

${ }^{b}$ There was no description of hardness on a label, however a value of hardness could be found on a manufacturer's website.

c The analytical value is below the lower limit of quantitation.

levels in comparison with those in the bottled water samples produced/consumed in the other countries such as Japan, China, South Korea, and Indonesia. The Cs concentrations $(<0.6 \mu \mathrm{g} / \mathrm{L})$ were also generally consistent with those of the other countries, and could be considered to be at sufficiently low levels. Our analytical results suggest that health risks from the trace elements in the bottled water samples of the Philippines are generally low, as well as daily life water consumed in Angono. ${ }^{1}$

Access to safe drinking water can be considered one of the most important challenges in global environmental policies. The UN MDGs Report ${ }^{12}$ laid out a reduction of 
Table 5. Concentrations of lead in bottled waters whose water sources are outside Japan

\begin{tabular}{|c|c|c|c|c|c|}
\hline \multirow{2}{*}{ Country } & \multirow{2}{*}{\multicolumn{2}{|c|}{ Sample }} & \multicolumn{2}{|c|}{ Lead concentration } & \multirow{2}{*}{$\begin{array}{c}\text { Hardness } \\
\text { on label }^{a}\end{array}$} \\
\hline & & & (ng/L) & RSD (\%) & \\
\hline France & FBW-K- & 1 & 9.3 & 1.4 & $\mathrm{MH}$ \\
\hline France & & 2 & 3.1 & 4.5 & $\mathrm{VH}$ \\
\hline France & & 3 & 13.3 & 1.3 & VH \\
\hline France & & 4 & 1.3 & 6.7 & VH \\
\hline France & & 5 & 2.0 & 1.6 & $\mathrm{MH}$ \\
\hline France & & 6 & 5.0 & 1.3 & VH \\
\hline Italy & & 7 & 1.4 & 2.0 & VH \\
\hline Italy & & 8 & 5.0 & 0.7 & $\mathrm{VH}$ \\
\hline USA & & 9 & 6.6 & 2.1 & $S$ \\
\hline Fiji & & 10 & 23.9 & 2.0 & $\mathrm{MH}$ \\
\hline Canada & FBW-P- & 1 & $<1.4^{b}$ & & $S$ \\
\hline
\end{tabular}

Notes: Sample names are common to those shown in Maruyama et al. [4]. FBW-K and FBW-P represent a bottled water purchase in Kyoto City and that got in regions outside Kyoto City, respectively. RSD: Relative Standard Deviation.

${ }^{a}$ Classification of water hardness is based on WHO [8]. S: soft; $\mathrm{MH}$ : moderately hard; $\mathrm{VH}$ : very hard.

${ }^{b}$ The analytical value is below the lower limit of quantitation.

people who cannot access to improved safe drinking water as a policy goal in 2010 . However, 663 million people worldwide still have to use unimproved drinking water resources, and $20 \%$ of them live in the South East Asia region. ${ }^{12}$ Therefore, some government agencies of the Philippines such as the Laguna Lake Development Authority (LLDA) and Department of Environment and Natural Resources (DENR) have been addressing this issue.

In the above-mentioned situation, the people living in the Philippines currently seem to regard commercial bottled water as "safe" drinking water. The trace-element concentrations of the bottled waters analyzed in this study were found in the completely safe levels. However, in the future, a third-party evaluation system of the scientificallyproven quality and safety of bottled water will need to be created as with daily life water (i.e., tap, well, and spring water) examined by Maruyama et al. ${ }^{1}$ Moreover, all the obtained information has to be broadly shared with not only bottled water producers for guarantee of safety/ quality of their products but also with all people living in the Philippines. These are important future issues for maintaining the quality and safety of all types of drinking water in the Philippines.

\section{Acknowledgments}

We are grateful to the Risk Management Laboratory at Japan University of Economics for the support provided to our study. We also thank Testing and Analysis Division of Shimadzu Techno-Research, Inc. for the analyses of the trace elements in the bottled waters of Indonesia.

\section{Statement of Authorship}

Kato and Maruyama conceived the idea to measure trace element concentrations in bottled water. Kato, Maruyama, and Juban corrected bottled water samples. Maruyama and Hirata carried out analyses. Maruyama processed analytical data, and wrote the paper. All authors approved the final version submitted.

\section{Author Disclosure}

All authors declared no conflicts of interest.

\section{Funding Source}

This study was partly supported by Grants-in-Aid for Scientific Research to HK (15K00672, FY 2015-2017) and TH (A26247094, FY 2014-2019) from the Ministry of Education, Culture, Sports, Science and Technology, Japan.

\section{REFERENCES}

1. Maruyama S, Kato H, Merino GJ, Hirata T, Juban NR. Concentrations of trace elements in daily life water consumed in Angono, Rizal, Philippines. Acta Med Philipp. 2020; 54(2):167-74.

2. WHO. Guidelines for drinking-water quality, 4th ed. Geneva, Switzerland: World Health Organization. 2011; pp. 541.

3. Lomboy M, Riego de Dios J, Magtibay B, Quizon R, Molina V, Fadrilan-Camacho V, et al. Updating national standards for drinkingwater: a Philippine experience. J Water Health. 2017 Apr; 15(2): 288-95. doi:10.2166/wh.2016.177.

4. Saito S, Nakano T. Evaluation of water quality of Laguna Lake watersheds. In: Proceedings of the 1st International Symposium on Managing Environmental Risks to Food and Health Security in the Laguna Lake Watersheds, Philippines. June 3, 2011, Kyoto, Japan, pp. 28-30.

5. Kada R. Strategy for survival of food and agriculture. Kyoto, Japan, Showado. 2014; 141 (in Japanese).

6. Solidum JN. Lead and cadmium levels in shell foods, raw vegetables and restaurant drinking water in Metro Manila, Philippines. Int J Chem Environ Eng. 2011; 2(4):234-7.

7. Reimann C, Birke $\mathrm{M}$, eds. Maps and their interpretation. In: Geochemistry of European bottled water. Stuttgart, Germany: Borntraeger Science Publishers. 2010; pp. 63-199.

8. Maruyama S, Hattori K, Hirata T. Concentrations of uranium and thorium in bottled mineral waters. Chikyukagaku (Geochemistry). 2014; 48(3):187-99 (in Japanese with English abstract and captions). doi:10.14934/chikyukagaku.48.187.

9. Kordas K, Canfield RL, López P, Rosado JL, Vargas GG, Cebrian $\mathrm{ME}$, et al. Deficits in cognitive function and achievement in Mexican first-graders with low blood lead concentrations. Environ Res. 2006 Mar; 100(3):371-86. doi:10.1016/j.envres.2005.07.007.

10. Miranda ML, Kim D, Galeano MAO, Paul CJ, Hull AP, Morgan SP. The relationship between early childhood blood lead levels and performance on end-of-grade tests. Environ Health Perspect. 2007 Aug; 115(8):1242-7. doi:10.1289/ehp.9994.

11. WHO. Hardness in drinking-water. Background document for preparation of WHO Guidelines for drinking-water quality. 2011. Geneva, Switzerland, World Health Organization (WHO/SDE/ WSH/03.04/9/Rev/1), pp. 11.

12. UN. Millennium Development Goals Report 2015 [Internet]. New York, United Nations. 2015 [cited 2020 Oct 7]. Available from: http://www.un.org/millenniumgoals/2015_MDG_Report/pdf/ MDG\%202015\%20rev\%20(July\%201).pdf 